\title{
CRETACEOUS ACULEATE WASPS FROM TAIMYR, SIBERIA (HYMENOPTERA)*
}

\author{
By Howard E. Evans \\ Museum of Comparative Zoology ${ }^{1}$
}

It seems incredible that only i6 years ago no aculeate Hymenoptera were known from the Mesozoic. In 1957 Sharov described Cretavus from the Upper Cretaceous, an enigmatic form almost certainly belonging to the Scolioidea. Ten years later Wilson, Carpenter, and Brown described a beautifully preserved worker ant from Upper Cretaceous amber, and in 1969 I described two dissimilar wasps from the Upper Cretaceous and an undoubted aculeate wing from the Lower Cretaceous. Thus within a few years it became evident that the Aculeata were well diversified by the end of the Mesozoic. Recent finds in the U.S.S.R. have more than confirmed that impression, and when fully described will document a radiation so pronounced that events in the Tertiary will appear anticlimactic.

It is the purpose of this brief report to provide names and descriptions for several striking wasps occurring in Upper Cretaceous amber from the Taimyr Peninsula, Siberia. These specimens were kindly made available to me for study by Dr. A. Rasnitsyn of the Palaeontological Institute of the U.S.S.R. Academy of Sciences, Moscow. All specimens have been returned for deposit in that institution. All specimens bear the following data, as supplied by Dr. Rasnitsyn: North Siberia, Taimyr Peninsula, Maimetcha River [a branch of the Kheta River, Khatanga Basin], Yantardakh Hill [3 km up from mouth of the Maimetcha]; amber of Upper Cretaceous age, Coniacian-Santonian stage, Kheta formation.

This material contains several relatively well-preserved, more or less complete specimens. As might be anticipated, some of them are quite generalized and difficult to place in the commonly accepted superfamilies. One of these I tentatively place in the Scolebythidae, a recently-described family that I consider annectant between the Scolioidea and Bethyloidea. Another I interpret as a probable gen-

*Published with the aid of a grant from the Museum of Comparative Zoology.

${ }^{1}$ Present address: Dept. of Entomology and Zoology, Colorado State Univ., Fort Collins, Colorado 80521.

Manuscript received by the editor, June 7, 1973. 
eralized sphecoid wasp. One specimen is quite clearly a sphecoid, a pemphredonine probably related to Lisponema, described from Cretaceous Canadian amber (Evans, 1969). The bulk of the material consists of Bethyloidea (26 of 29 specimens), including the first records of Bethylidae from prior to the Oligocene.

As might be expected, all specimens are small (under $5 \mathrm{~mm}$ ) and all represent forms likely to be associated with trees. Present-day Bethylidae attack larvae of Microlepidoptera and small Coleoptera, while Cleptidae (the most abundant Aculeata in Taimyrian amber) are parasites of sawfly larvae or the eggs of Phasmida. Many living Pemphredoninae are associated with woody plants, and since the Cretaceous forms lack spinose legs it seems a safe assumption that they were xylicolous. The absence of larger wasps and of fossorial forms is, I believe, merely an artifact, as such insects are unlikely to become fossilized in small pieces of resin. But the diversity of nonfossorial forms leads one to believe that the total aculeate fauna may have been surprisingly rich.

\section{? FAMILY SPHECIDAE}

\section{Taimyrisphex, new genus}

Known from a single male approximately $4 \mathrm{~mm}$ in length, fully alate [legs missing except coxae, front and middle trochanters, and front femur] (Figs. I, 2). Head about as wide as thorax; lower part of front roundly prominent, overhanging bases of antennae, the latter 13-segmented, very short, approximately capable of reaching apices of front coxae, scape barely longer than thick, flagellar segments about as long as thick (except ultimate segment $1.5 \times$ as long as thick); eyes large, reaching from close to top of vertex to base of mandibles, inner margins weakly emarginate; ocelli large, lateral ocelli removed from eye margins by less than their own diameters; occipital carina present at least laterally; labial palpi short, 4-segmented; maxillary palpi slightly longer [probably 6segmented; details of mandibles and clypeus not clearly visible]. Pronotum sloping smoothly to collar, with small, rounded posterior lobes which nearly reach the tegulae; dorsal and lateral faces of pronotum separated by a subcarinate ridge; posterior margin of pronotum forming a smooth arc between posterior lobes; mesoscutum long, weakly convex, the notauli deeply and broadly impressed on the posterior fourth, extending as weak lines almost to anterior margin of scutum; parapsidal furrows present, linear, nearly complete; scutellum convex, with a transverse basal impres- 
sion; metanotum rather long, but postnotum not visible; propodeum with smooth contours, posterior rim well developed; mesopleurum strongly convex, undivided by grooves; mesosternum simple; middle coxae contiguous; coxae subconical; front femur simple, elongate. Wing venation as figured. Metasoma sessile; tergite I convex, forming a weak constriction at junction with tergite 2 ; sternite I nearly flat in profile, hind margin nearly straight, thin, slightly overlapping base of sternite 2 , which has a narrow basal constriction beyond which it is strongly convex [apical third of metasoma missing].

Type-species. - Taimyrisphex pristinus, new species.

Remarks. - This is an exceedingly generalized aculeate, without noteworthy features that would assign it unequivocally to any major group. I assign it tentatively to the Sphecidae (in the broad sense), largely on the basis of the rounded posterior lobes of the pronotum, which lie slightly below the tegulae and do not quite reach them. The wing venation is not inconsistent with that of a generalized sphecid, and is more generalized than that of Archisphex (Evans, 1969) with respect to the position of the recurrent veins. The venation might also be that of a generalized scolioid, although the lack of a constriction between the first two metasomal segments and of a crease beneath the stigma ( $1 \mathrm{r}$ ) would exclude it from most living families of Scolioidea. The general form of the pronotum is suggestive of a pompilid, and the venation would not exclude it from that family, but there is no evidence of a transverse suture on the mesopleurum. Since we know from other evidence that the family Sphecidae was well represented in the Cretaceous, it seems best to assign Taimyrisphex to that family, at least tentatively, until such time as further pieces can be added to the puzzle.

\section{Taimyrisphex pristinus, new species}

Length about $4 \mathrm{~mm}$; fore wing about $2.5 \mathrm{~mm}$. Color dark brown, pronotum apparently with a pair of dorsal pale spots, first metasomal

Fig. 1. Taimyrisphex pristinus, n. sp., wings of type. Fig. 2. Same specimen, oblique-dorsal view of body, wings mostly omitted. Fig. 3. Mandible of Cretabyt/lus sibiricus, n. sp. type. Fig. 4. Same specimen, body and wings. Fig. 5. Pittoecus pauper, n. sp., type, portion of fore wing. Fig. 6. Same specimen, front leg. Fig. 7. Same specimen, hind tibia. Fig. 8. Same specimen, ventral surface of abdomen. Fig. 9. Protamisega khatanga, n. sp., type, lateral view of head. Dashed lines in Figures 4 and 5 indicate parts not clearly visible in specimens. 

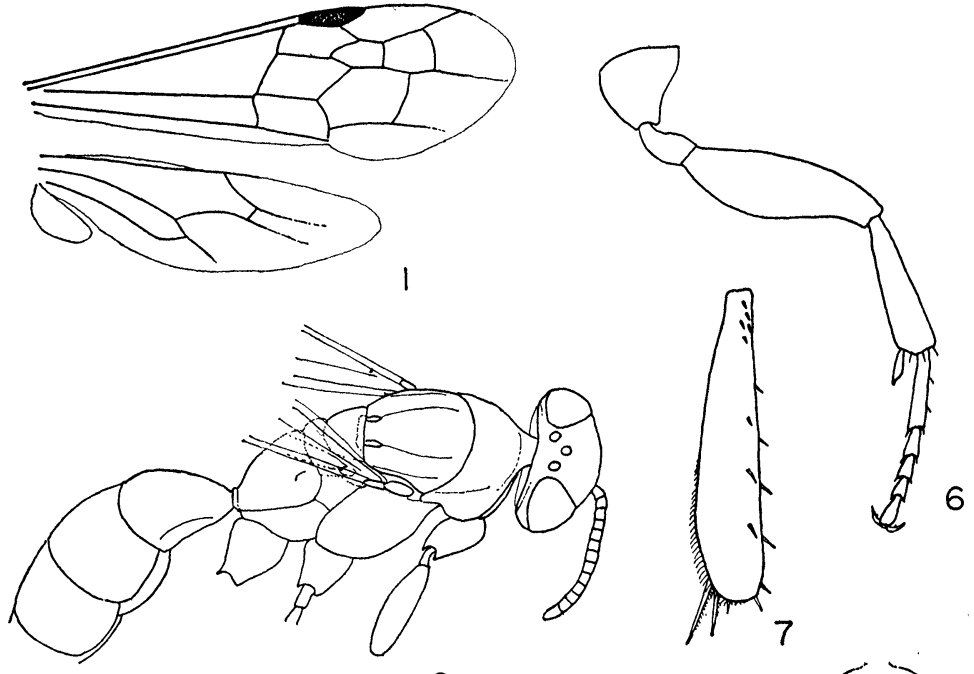

2
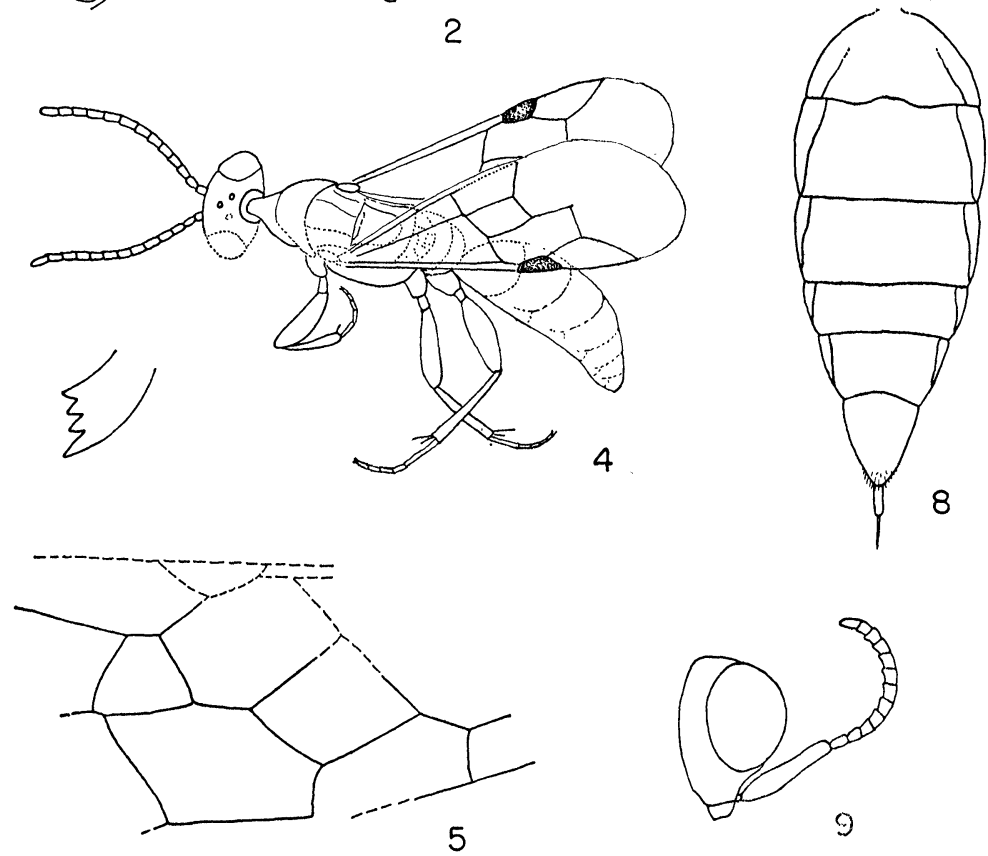
tergite with a pair of large pale spots barely separated medially [these maculations may be artifacts]; antennae dark brown except scape paler; preserved parts of legs stramineous except hind coxae mostly fuscous; wings hyaline, with brown veins and stigma; wing membrane covered with microtrichiae, but body without visible setae or pubescence. Body surface smooth, without noticeable sculpturing. Front angle of ocellar triangle exceeding a right angle; lateral ocelli removed from eye margin by slightly less than half their own diameters, removed from the rounded vertex crest by somewhat more than their own diameters. Front femur $3 \times$ as long as its maximum width.

Holotype. - o , Taimyr, N. Siberia, I970, amber specimen no. 3130-16.

\section{FAMILY SPHECIDAE: SUBFAMILY PEMPHREDONINAE}

Pittoecus, new genus

Known from a single female approximately $5 \mathrm{~mm}$ in length, fully alate but with a reduced wing venation resembling that of certain living Pemphredonini (Figs. 5-8). Head broad, with large eyes extending from base of mandibles to or close to top of head; temples broad; antennae short, I2-segmented, somewhat coiled, arising from small elevations of the front; mandibles straight, tapered, without visible teeth on upper or lower margin [clypeus and other mouthparts not clearly visible, top of head (including ocelli) missing]. Pronotum with rounded posterior lobes similar to those of living Pemphredoninae [thoracic dorsum largely missing]; mesopleura somewhat convex, without visible grooves; legs fully preserved, with only a few small spines, front tarsus without a pecten, hind tibia with a group of very short spines basally and a few along the shaft; tibial spur formula I-I-2; claws dentate. Wings imperfectly preserved, fore wing apparently with two submarginal cells, as figured. Metasoma slender and tapered, sessile basally, with six distinct segments and a well developed sting and sting-palps [dorsum of abdomen missing].

Type-species. - Pittoecus pauper, new species.

Remarks. - Although the only available specimen is incomplete, consisting of a hollow mold of the ventral half of the body (with complete legs and partially complete wings), the form is so similar to that of living pemphredonine wasps such as Passaloecus that it seems worthy of description. The form of the second submarginal cell and the unusual distance between the origin of the basal and 
transverse median veins are suggestive of the Australian genus Harpactophilus.

\section{Pittoecus pauper, new species}

Length $4.8 \mathrm{~mm}$; estimated length of fore wing $2.5 \mathrm{~mm}$. Coloration not preserved, specimen the color of amber. Scape barrelshaped, about twice as long as wide; antennal segments 2-12 slightly longer than thick, I3 somewhat pointed, about I.7 $\times$ as long as thick. Front femur 2.7 $\times$ as long as wide; segments of front tarsus in a ratio of $25: 8: 7: 6: 13$, comparable measurements of hind tarsus $45: 18: 14: 8: 13$; front basitarsus with two minute lateral spines as well as some small apical ones; hind tibia with short spines as figured, hind tarsi also weakly spinose. Apical metasomal segment bearing numerous short bristles adjacent to base of sting.

Holotype. - 9 , Taimyr, N. Siberia, I970, amber specimen no. 3130-1 8 .

\section{? FAMILY SCOLEBYTHIDAE}

\section{Cretabythus, new genus}

Known from a single male approximately $2.5 \mathrm{~mm}$ in length, fully alate but with a reduced venation, hind wing without closed cells (Figs. 3, 4). Antennae elongate, I3-segmented, all segments somewhat longer than wide; maxillary palpi elongate [probably 6-segmented]; mandibles short, with 4 sharp apical teeth; clypeus, short, with a low median keel; malar space short, about one fourth as long as width of mandibles at their base; eyes and ocelli of moderate size, ocelli in a broad triangle close to the broadly rounded vertex; head contracted immediately behind eyes; occipital carina complete. Pronotum short, its posterior margin broadly arched between the posterior lobes, which are small, rounded, slightly below and touching the tegulae; pronotum with a short, anterior collar; notauli and parapsidal furrows complete; scutellum large, rather flat; base of propodeum with a slightly elevated, transverse band (?metanotum), disc with a basal, semicircular area with strong surface sculpturing, otherwise smooth, with a strong transverse carina margining the abrupt, posterior declivity. Propleura well developed, somewhat prolonged anteriorly, but posternum and proepimeron (as described for Scolebythus) not evident; mesopleura rather smooth, without evident pits, ridges, or sutures; front and hind coxae contiguous, middle coxae slightly separated. Fore wings as figured, with one 
closed submarginal cell and two closed discoidal cells (superficially resembling certain pemphredonine Sphecidae); hind wing not fully visible, but evidently with a strong vein on the basal, anterior margin, without closed cells. Legs not spinose; tibial spur formula I-2-2; claws dentate. Metasoma slender, sessile, with 7 visible segments, without a constriction between first two segments and without unusual modifications.

Type-species. - Cretabythus sibiricus, new species.

Remarks. - This specimen is reasonably well preserved and nearly complete, but it presents a puzzling combination of characters. I had at first supposed it was a pemphredonine sphecid related to Pittoecus, but despite similarities in the wing venation there are several reasons for excluding it from this group: the broad, 4-toothed mandibles, pronotal lobes reaching the tegulae, two mid-tibial spurs, lack of closed cells in the hind wing, and so forth. The wing venation appears closest to that of the Scolebythidae (though unfortunately one cannot be sure whether the anal lobe is developed) and there are other features in common with that group. ${ }^{2}$ However, there are also several major differences: e.g. lack of a distinct prosternum and proepimera, presence of an anterior pronotal collar and of a transverse carina on the propodeum, and differences in the form of the first metasomal segment. It is probable that modern Scolebythidae are specialized for life beneath bark or in holes in wood, and the absence of such specializations in Cretabythus should not necessarily exclude it from this family. For the present I can suggest no better placement for this unusual wasp.

\section{Cretabythus sibiricus, new species}

Length $2.5 \mathrm{~mm}$; fore wing about $\mathrm{I} .9 \mathrm{~mm}$. Fuscous, except pronotum apparently somewhat lighter than remainder of body; legs stramineous; antennae stramineous basally, slightly infuscated toward apex; wings hyaline, stigma brown, veins light brown. Body without strong surface sculpturing and without noticeable setae. Antennal segments in the following ratio: $5: 4: 5: 5: 5: 5: 5: 5: 5: 5: 5: 5: 5$; segment three about $1.7 \times$ as long as wide. Segments of front tarsus in a ratio of $8: 4: 3: 2: 5$; longer spur of hind tibia $0.4 \times$ length of hind basitarsus.

\footnotetext{
${ }^{2}$ When I described the Scolebythidae (Evans, 1963) I had only females. I have since discovered a male Clystopsenella longiventris Kieffer and can state that there is no marked sexual dimorphism in this group. The family currently has a broadly discontinuous distribution in Brazil, Madagascar, and Australia (the Australian element has yet to be described).
} 


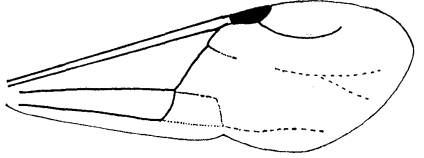

10

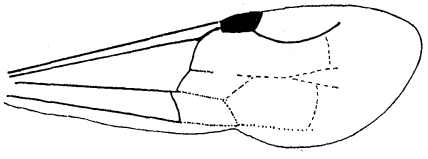

12
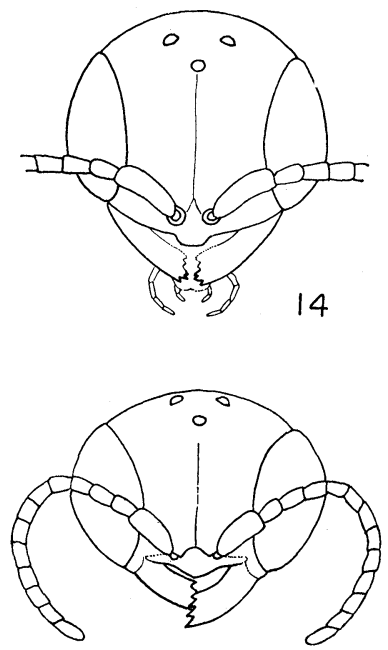

15

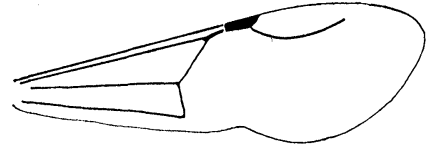

11
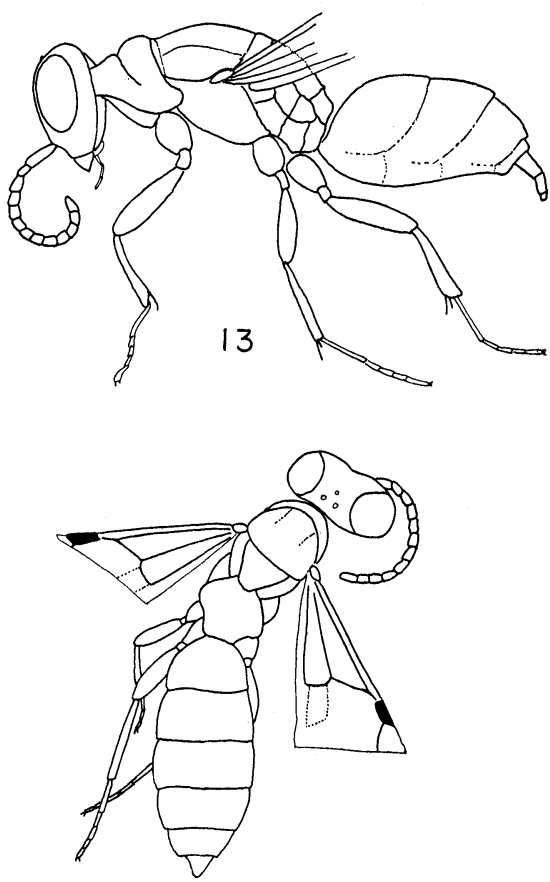

16

Fig. 10. Protamisega khatanga, n. sp., type, fore wing. Fig. 11. Hypocleptes rasnitsyni, n. sp., type, fore wing. Fig. 12. Archaepyris minutus, n. sp., type, fore wing. Fig. 13. Hypocleptes rasnitsyni, n. sp., lateral view of type. Fig. 14. Celonophamia taimyria, n. sp., head of type. Fig. 15. Archaepyris minutus, n. sp., head of type. Fig. 16. Celonophamia taimyria, n. sp., dorsal view of body and wings as preserved. Broadly dashed lines in Figures 10 and 12 indicate pale streaks in wing membrane, while finely stippled lines indicate weak veins. 
Holotype. $-0^{\star}$, Taimyr, N. Siberia, I970, amber specimen no. 3130-1 7 .

\section{FAMILY BETHYLIDAE \\ Archaepyris, new genus}

Wasps approximately $2 \mathrm{~mm}$ in length, fully alate, of fuscous coloration (known only from males) (Figs. 12, I5). Antennae simple, with 13 segments; eyes large, slightly protruding from sides of head, not noticeably hairy; mandibles short, broad, with several sharp apical teeth; clypeus short, median lobe only slightly produced; ocelli of moderate size, situated close to vertex crest. Pronotum moderately long, disc only slightly shorter than mesoscutum along midline; notauli and basal scutellar pits or groove not visible; propodeum short, with a more or less flat dorsal surface that is slightly wider than long, also with an almost vertical posterior declivity. Legs not spinose; claws weakly dentate. Fore wing as figured, with a short vein arising from basal vein, the discoidal cell outlined by weak veins and outer part of wing with a series of fine creases that may mark the course of former veins. Metasoma sessile.

Type-species. - Archaepyris minutus, new species.

Remarks. - Since the classification of Bethylidae is based on structural minutiae that require perfect preservation and close study under high power, placement of fossil material involves a large measure of guess work. Archaepyris I would judge to be a very generalized bethylid, combining features of the usually recognized subfamilies. Although Epyris-like in general form, the venation is suggestive of some Pristocerinae, while the vein arising from the basal vein suggests Bethylinae.

\section{Archaepyris minutus, new species}

Length $2 \mathrm{~mm}$; fore wing $1.4 \mathrm{~mm}$. Fuscous; wings hyaline, with brown veins and stigma. Front slightly narrower than eye height, with a weak median groove; sculpturing of front rather weak; antennae arising close to base of clypeus, the segments in the following ratio: $15: 10: 9: 10: 9: 9: 9: 9: 9: 9: 9: 9: 15$. Segments of middle tarsus in the following ratio: $16: 7: 7: 5: 9$. Subgenital plate simple; parameres hirsute, somewhat rounded apically.

Holotype. - ot, Taimyr, N. Siberia, 1971, amber specimen no. 33II-7. Paratype. $-\sigma^{*}$ in fair condition, in amber from same source, no. 3130-2I. 
Celonophamia, new genus

Wasps approximately $2 \mathrm{~mm}$ in length, fully alate, of fuscous coloration (known only from females) (Figs. I4, I6). Antennae simple, with 12 segments; eyes large, slightly protruding from sides of head, not noticeably hairy; palpi short; mandibles short, the apex broad, with several sharp teeth; front with a deep median groove. Pronotum short, its posterior margin broadly arched; mesoscutum broad, notauli distinct. Legs simple, not spinose; front femur not swollen, about $3 \times$ as long as wide; claws simple. Wings extending well beyond middle of abdomen, rather evenly covered with microtrichiae; stigma and radial vein well developed; basal vein reaching subcosta a short distance basad of stigma, not giving rise to a vein; discoidal and subdiscoidal veins absent or weakly defined. Metasoma sessile, slightly flattened, bearing short bristles.

Type-species. - Celonophamia taimyria, new species.

Remarks. - This genus also occurs in Upper Cretaceous Canadian amber (specimen to be described later). The i2-segmented antennae suggest Cephalonomia and its allies (the generic name is anagram of Cephalonomia). However, the wings are broader and have a fuller venation than in that genus. Possibly this genus is close to the ancestral stock of the Cephalonomiini, subfamily Epyrinae.

\section{Celonophamia taimyria, new species}

Length $2 \mathrm{~mm}$; fore wing about I.3 mm. Fuscous; wings hyaline, with brown veins and stigma. Front slightly wider than height of an eye, with a deep median sulcus reaching to anterior ocellus; ocelli of moderate size; sculpturing of front weak. Antennal segments in the following ratio: $15: 8: 7: 6: 6: 6: 6: 6: 6: 6: 6: 10$. Segments of hind tarsus in the following ratio: 20:9:7:6:1 I.

Holotype. - + , Taimyr, N. Siberia, 1971, amber specimen no. 33I I-5. Paratypes. - Two specimens of indeterminate sex, in rather poor condition, nos. 33II-II and 33II-I2.

\section{FAMILY CLEPTIDAE}

\section{Hypocleptes, new genus}

Small wasps bearing much resemblance to living members of the genus Cleptes, although with a very simple wing venation (known only from females) (Figs. II, I3). Antennae short, scape only about $2.5 \times$ as long as wide, arising slightly below bottoms of 
eyes; malar space moderately long; palpi simple, slender. Pronotum rather long, crossed by a deep transverse furrow, posterior lobes projecting well beneath sides of mesoscutum, the latter elongate, with strong, complete notauli; propodeum strongly foveolate, somewhat angulate but not really dentate on each side. Fore wing with very simple venation, as figured. Legs simple, slender, non-spinose; tibial spur formula I-2-2; claws apparently simple. Metasoma robust except apical three segments in the form of a slender (probably extensible) tube. Body without strong surface sculpturing except for the large foveae on the propodeum.

Type-species. - Hypocleptes rasnitsyni, new species.

Remarks. - This genus differs from Procleptes (Evans, 1969) in lacking dentiform processes on the propodeum and apical processes on the front coxae; also, the scapes are much shorter. The wings of Procleptes are mostly missing, so this feature cannot be compared.

\section{Hypocleptes rasnitsyni, new species}

Length $2.8 \mathrm{~mm}$; fore wing about $1.8 \mathrm{~mm}$. Head, thorax, and appendages brown to black, abdomen much paler, rufotestaceous; wings hyaline, veins and stigma brown. Antennae short, middle segments very slightly longer than wide. Mesoscutum, measured along midline, about twice as long as pronotum, surface sparsely punctate; mesoscutum and scutellum separated by a transverse groove. Segments of front tarsus in the following ratio: 22:5:5:4:10; middle and hind tarsi more elongate than front tarsi.

Holotype. - o, Taimyr, N. Siberia, I97I, amber specimen no. 33I I-6. Paratypes. -5 of in fair condition in other pieces of amber from same source, nos. 3130-20, 3130-22, 331I-8, 33II-9, and 33 I I-IO. 4 additional 우 in poor condition are also tentatively placed in this species.

\section{Protamisega, new genus}

Known from a single female only $\mathrm{r} .9 \mathrm{~mm}$ in length, bearing much resemblance to living members of the genus Amisega (Figs. 9, IO). Eyes large, somewhat protuberant; antennae inserted far below bottom of eyes, scape very long, about $4 \times$ as long as wide, about half as long as remainder of antenna. Pronotum moderately long, crossed by a transverse carina anteriorly, midline not impressed; notauli deeply impressed, complete; scutellum with a transverse basal sulcus; propodeum with a steep posterior slope, surface with a number 
of ridges describing large foveae, ridges on sides converging to form a small, spinose projection. Legs simple, not spinose; claws apparently simple. Fore wing as figured. Metasoma robust on basal four segments, terminal segments forming a tube very much as in Hypocleptes. Body without noticeable setae and without strong surface sculpturing except for propodeum.

Type-species. - Protamisega khatanga, new species.

Remarks. - This genus differs from the preceding in having the wing venation less simplified and in having the scape longer and inserted lower on the head. In the last feature it resembles Procleptes of Canadian amber (Evans, I969), but the latter has stronger processes on the propodeum and much more obvious surface sculpturing.

\section{Protamisega khatanga, new species}

Length $1.9 \mathrm{~mm}$; fore wing $\mathrm{I} .2 \mathrm{~mm}$. Body dark brown, scape and basal parts of legs also fuscous, but appendages fading to lighter brown apically; wings hyaline, veins and stigma light brown. Antennae prominent, middle segments about as wide as long. Segments of hind tarsus in the following ratio: $17: 6: 6: 5: 9$. First four metasomal tergites in approximately the following ratio, measured from the side: $13: 13: 8: 4$. The terminal tubular portion appears to be made up of three segments, although the details are obscure.

Holotype. 一 + , Taimyr, N. Siberia, I970, amber specimen no. 3I 30-19.

\section{Discussion}

Ten additional pieces of amber from the same source contain unidentifiable specimens, all of which I would judge to be Bethyloidea; some of these probably represent additional specimens of species described above. The preponderance of Bethyloidea in this material doubtless reflects the fact that many are associated with trees and are small enough to be preserved in small pieces of amber, as mentioned earlier. Nevertheless it is difficult to escape the impression that Cleptidae, at least, were much more abundant than they are today, for the family is now represented by only a few genera containing species that are only rarely encountered. Since the Cretaceous Cleptidae have the general habitus of contemporary forms, it is perhaps a safe assumption that they, too, attacked Symphyta and Phasmida, groups that may well have been more important parts of the fauna in the Cretaceous than they are today. 
All of the Bethyloidea are clearly identifiable as to family, but more difficult to place in present-day tribes and subfamilies. The bethylid genus Archaepyris appears to have some features of each of the major subfamilies, while Celonophamia appears annectant between the Epyrini and Cephalonomiini. Cretabythus is a truly enigmatic form, with many bethylid-like features (particularly the mandibles) but with an unusual wing venation suggesting the Scolebythidae. Taimyrisphex is perhaps the most generalized wasp yet described from the Cretaceous. Although I have placed it in the Sphecidae, one might argue that it is a scolioid or even a prototype of the Pompilidae. We do know that the Sphecidae underwent considerable evolution before the end of the Cretaceous, for two specialized forms of the subfamily Pemphredoninae have now been described.

In conclusion, it may be useful to list the Aculeata now known from the Cretaceous, bearing in mind that this list will be considerably augmented when all recently collected material has been described:

SCOLIOIDEA

Cretavidae: Cretavus

?SCOLIOIDEA-BETHYLOIDEA

?Scolebythidae: Cretabythus

BETHYLOIDEA

Bethylidae: Archaepyris Celonophamia

Cleptidae: Procleptes Hypocleptes Protamisega
FORMICOIDEA

Formicidae: Sphecomyrma

?SPHECOIDEA

?Sphecidae: Archisphex

Taimyrisphex

\section{SPHECOIDEA}

Sphecidae

Pemphredoninae: Lisponema

Pittoecus

\section{REFERENCES}

Evans, H. E.

1963. A new family of wasps. Psyche, 70: 7-16.

1969. Three new Cretaceous aculeate wasps (Hymenoptera). Psyche, 76: 251-261.

Sharov, A. G.

1957. First discovery of a Cretaceous stinging hymenopteron (Aculeata). Dokl. Akad. Nauk., 112: 943-944. (In Russian).

Wilson, E. O., F. M. Carpenter, and W. L. Brown, Jr.

1967. The first Mesozoic ants, with the description of a new subfamily. Psyche, 74: 1-19. 

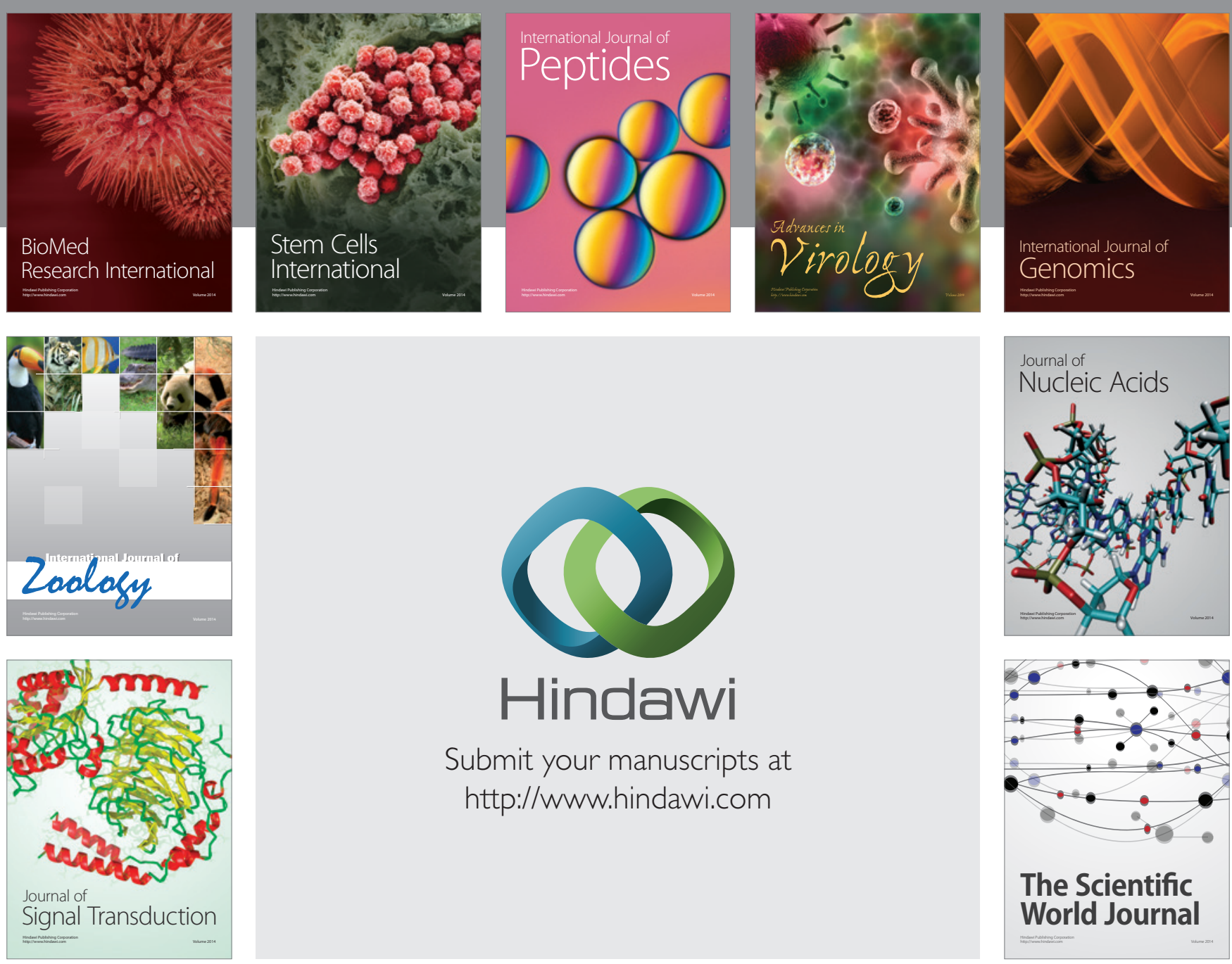

Submit your manuscripts at

http://www.hindawi.com
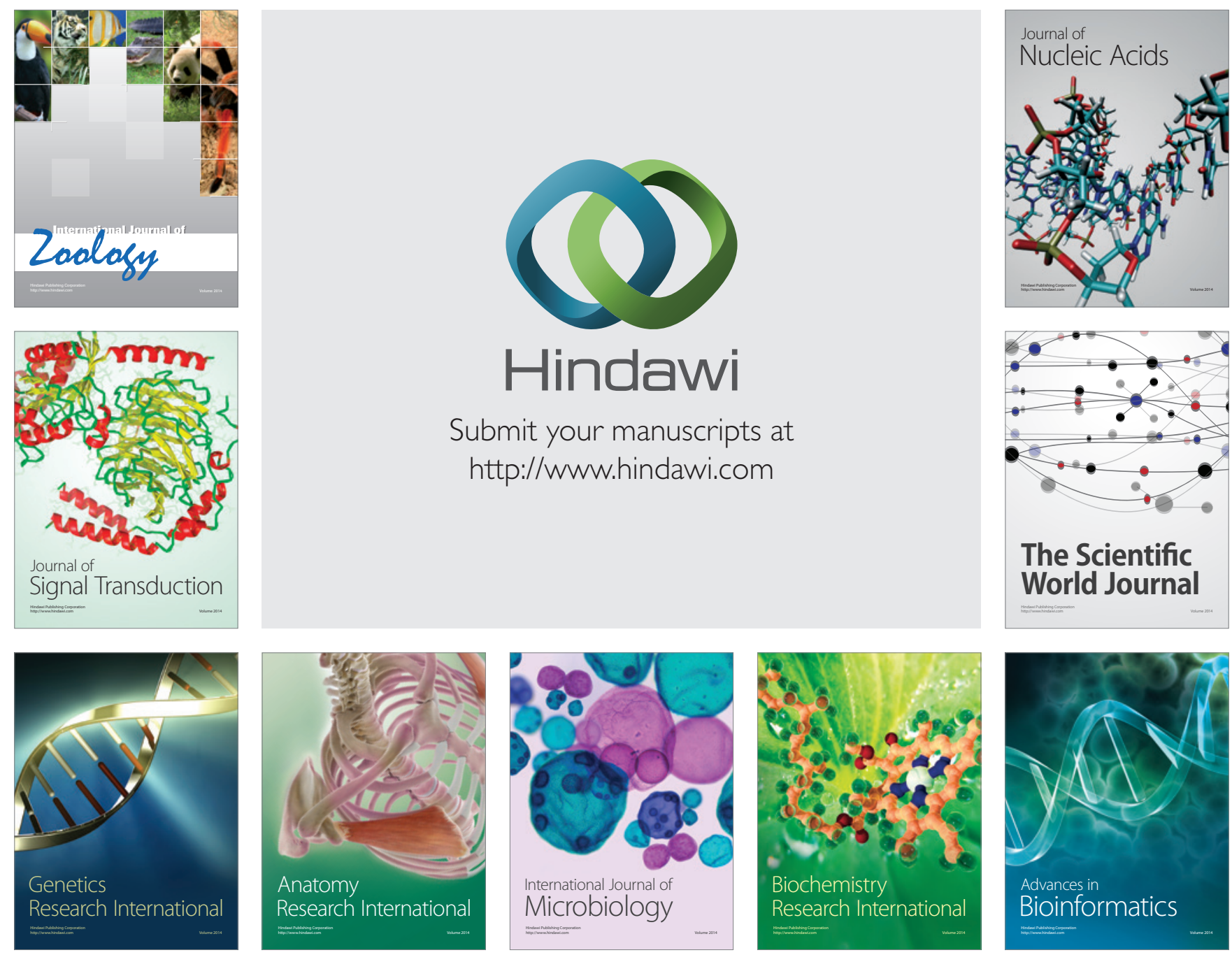

The Scientific World Journal
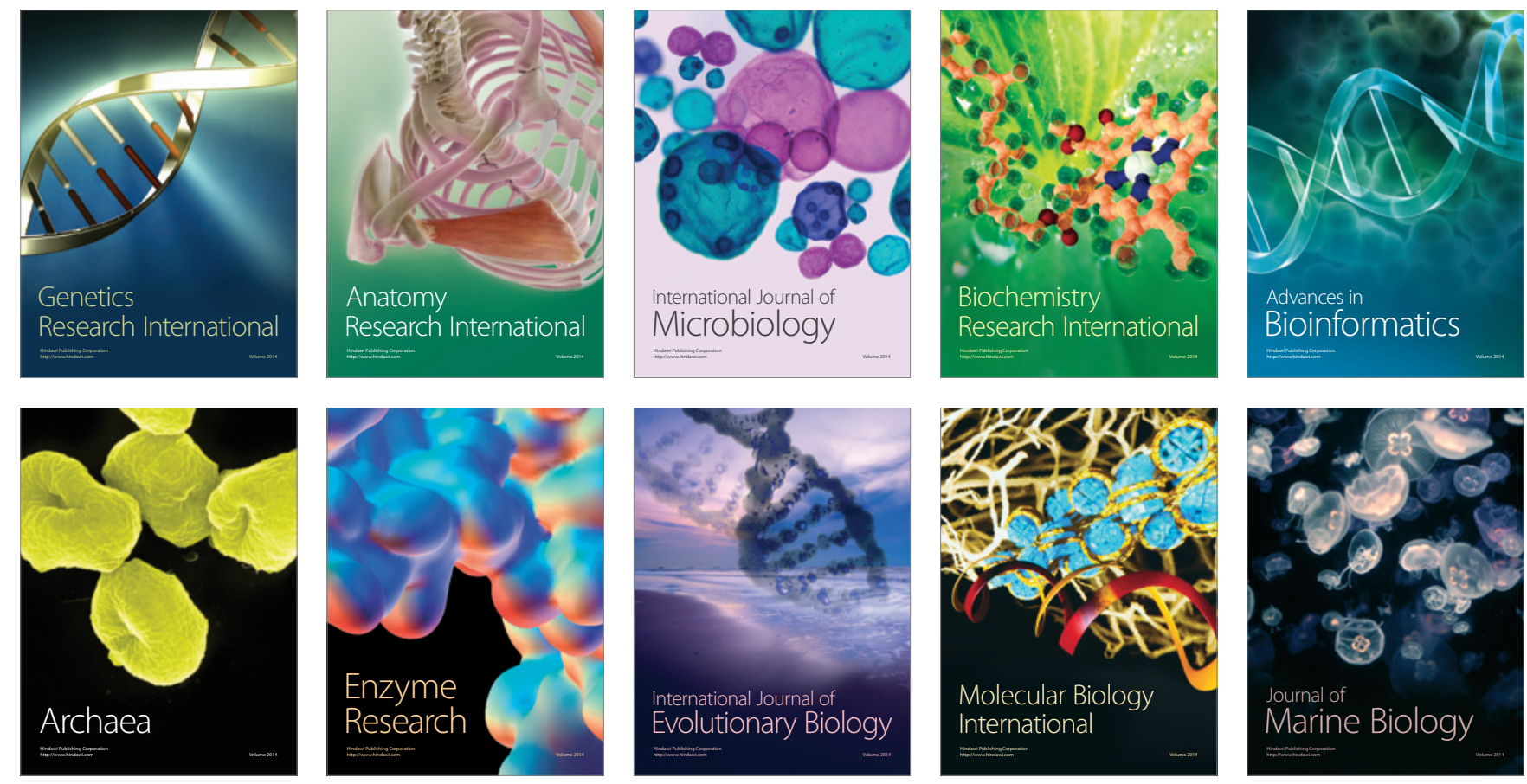